\title{
JUDICIALIZING POLITICS, POLITICIZING LAW
}

\author{
JOHN FEREJOHN*
}

I

INTRODUCTION

Since World War II, there has been a profound shift in power away from legislatures and toward courts and other legal institutions around the world. This shift, which has been called "judicialization," has become more or less global in its reach, as evidenced by the fact that it is as marked in Europe, and especially recently in Eastern Europe, as it is in the United States. The spectacles of Italian judges undermining Italy's postwar system of musical cabinets, or of newly energized French judges hounding prime ministers and presidents, are only the most visible aspects of these developments. One could also point to the role, and recent success, of judges in seeking to arrest and prosecute dictators and military leaders. Additionally, our own United States Supreme Court's intervention into electoral politics in Bush v. Gore ${ }^{2}$ was yet another manifestation of this trend.

One can distinguish at least three ways in which courts have taken on new and important roles relative to legislatures. First, courts have been increasingly able and willing to limit and regulate the exercise of parliamentary authority by imposing substantive limits on the power of legislative institutions. Second, courts have increasingly become places where substantive policy is made. Third, judges have been increasingly willing to regulate the conduct of political activity itself - whether practiced in or around legislatures, agencies, or the electorate-by constructing and enforcing standards of acceptable behavior for interest groups, political parties, and both elected and appointed officials.

But judicialization is not simply limited to the increasingly important, pervasive, and direct roles that courts play in making policy. The fact that courts frequently intervene in policy-making processes also means that other political actors, as well as groups seeking political action, have reason to take the

Copyright (C) 2002 by John Ferejohn

This article is also available at http://www.law.duke.edu/journals/65LCPFerejohn.

* Carolyn S.G. Munro Professor of Political Science, Senior Fellow of the Hoover Institution, Stanford University; Visiting Professor of Law and Politics, New York University School of Law.

Thanks are due to William Eskridge, Barry Friedman, and Pasquale Pasquino for helpful comments and observations.

1. Alex Stone Sweet, Governing With Judges 1 (2000); John Ferejohn \& Pasquale Pasquino, Rule of Democracy and Rule of Law, in DEMOCRACY AND THE RULE OF LAW (Jose Maria Maravall \& Adam Przeworski eds., forthcoming 2002).

2. 531 U.S. 98 (2000). 
possibility of judicial reaction into account. Proposals need to be framed in a way to ensure that legislation will neither be struck down nor interpreted in undersirable ways. In order to achieve such a result, part of the policy debate over new legislation must aim at anticipating the response of legal institutions. So, we see a global application of one aspect of the phenomenon that de Tocqueville noted about American politics years ago: the transformation of political questions into legal ones. ${ }^{3}$ This means that legal/constitutional considerations and rhetoric assume new and sometimes decisive importance in ordinary legislative policy-making.

One aspect of judicialization can be observed in the widespread adoption of institutions and practices of constitutional adjudication, even in places with legal institutions and traditions that had long been inhospitable to this process. True, the modes of constitutional adjudication adopted in Europe and elsewhere do not precisely follow the U.S. model. Ordinary European judges are not permitted to strike down legislation; that authority is confined to specialized constitutional courts located outside the judicial system. Nevertheless, many of these new European constitutional courts have been at least as willing to invalidate and modify parliamentary legislation as the U.S. Supreme Court has been-even in its most activist periods. ${ }^{4}$ Moreover, the existence of constitutional courts has, in effect, pressed ordinary judges to take account of constitutional issues in their everyday judicial activities. For example, European judges regularly interpret legislative statutes and administrative ordinances in view of the constitution and decide which issues need to be referred to the constitutional court. ${ }^{5}$ Moreover, the rise of constitutional adjudication has transformed the landscape of parliamentary politics by forcing legislators to take constitutional considerations into account when crafting legislative schemes. ${ }^{6}$

Perhaps as important as the invention of constitutional courts is the creation of supernational judicial institutions in Luxembourg and Strasbourg, namely the European Court of Justice and the European Court of Human Rights. These institutions have increasingly limited the capacities of national political institutions to make and implement domestic and international policy. Indeed, the incorporation of human rights jurisprudence in European states has given ordi-

3. AleXis De ToCQUeVILle, 1 Democracy IN AMERICA 280 (Vintage Edition 1945, reprinted 1990) ("Scarcely any political question arises in the United States that is not resolved, sooner or later, into a judicial question.").

4. STONE SWEET, supra note 1, at 1 ("Constitutional judges routinely intervene in legislative processes, establishing limits on law-making behavior, reconfiguring policy-making environments, even drafting the precise terms of legislation."). See also Christine Landfried, Germany, in THE GLOBAL EXPANSION OF JUDICIAL POWER 309 (C. Neal Tate \& Torbjorn Vallinder eds., 1995) (discussing the German constitutional court).

5. John Ferejohn \& Pasquale Pasquino, Deliberative Institutions, in CONSTITUTIONAL Justice, EAST AND WEST (W. Sadurski ed., forthcoming 2002).

6. STONE SWEET, supra note 1, at 194-204 (arguing that constitutional courts assume a "pedagogical function" with respect to legislatures, which are induced to take constitutional issues into account when legislating). 
nary judges much more power to challenge legislation. ${ }^{7}$ Even British judges can now review and challenge acts of Parliament, a circumstance that was inconceivable just a few months ago. In effect, there are now three judiciaries in Europe that can review legislation: ordinary judges, constitutional justices, and the justices serving on the European Courts. In addition, the systems in places such as Eastern Europe and Latin America are moving in this direction as well.

In the United States, we have a long history of courts' determining constitutional limits for legislatures. ${ }^{8}$ To be sure, those limits have fluctuated over time, and their contents remain deeply in dispute-both normatively and descriptively-among scholars, judges, and politicians. Moreover, judges have long engaged in substantive policy-making in this country as well. But the third strand of change-judicial regulation of the conduct of political life-has clearly increased over the past few decades. Courts have been playing an increasingly active-even an aggressive-role in such affairs as election regulation, campaign finance, organization of parties and interest groups, and maintenance of the electoral system. More recently, and more controversially, courts have even begun to regulate internal congressional processes by enforcing what might be called "deliberative requirements" on legislative action." This results not only in more legislation being made in courts, but also in subjecting legislation that is made in other institutions to process-based judicial regulation.

In view of these developments, it is no surprise that appointments to both the U.S. Supreme Court and to other federal courts have become partisan political issues. This has been true since the early days of the republic, although the intensity and frankness of the conflict has fluctuated over time. Particularly when the courts have systematically attempted to block or overturn the action of political majorities - as happened in the 1930s - there are often overt partisan fights over who should serve on the courts. These struggles are often seen as occasions in which principles of democracy-or at least some conception of democracy-come into conflict with legal principles-or at least some conception of those principles. Not surprisingly, such occasions put particular stress on the constitutional links between the political and judicial branches of government.

To some extent, the political aspect of court appointments is both inevitable and legitimate in our governmental structure. Democratic responsiveness and legality are complex and sometimes conflicting ideals. What each of them re-

7. Judges cannot invalidate laws or administrative actions, but they can declare them inconsistent with the European Convention for Human Rights and urge the governments to bring their domestic laws into conformity with the Convention. Laurence R. Helfer and Anne-Marie Slaughter, Toward a Theory of Effecting Supernational Adjudication, 107 YALE L. J. 273, 293-95 (1997).

8. To be precise, for most of our history, courts have primarily been active in acting as a check for state and local governments, but over much of the last century, federal legislation has been subjected to searching judicial scrutiny as well. The one period of judicial grace, beginning in 1937, was fleeting; this period truly reflected a shift in the content of the rights that courts would protect, from economic to personal rights. The defining statement of this shift is in the famous footnote four in U.S. v. Carolene Products Co., 304 U.S. 144, 153 n.4 (1938).

9. See Ruth Colker \& James J. Brudney, Dissing Congress, 100 MiCH. L. REV. 80, 83 (2001). 
quires at any point in time is an open and contested question. Practices of judicial rule-making are right at the contested boundary of these concepts. Furthermore, when the domain of courts includes the making of general rules that affect everyone and not just actual litigants-as it does in constitutional courts-we should expect popular and political reactions. While courts are legislating, all of us have a legitimate interest in who sits on them. While court appointments are inevitably political, they are not always partisan. When courts become politicized in a partisan sense, matters become more troubling. Democracies produce shifting majorities, and if shifts in partisan control translate into judgeships, then the content of law becomes unstable.

First, this article will argue that what is at stake, institutionally, is the allocation of legislative power-the power to establish general rules of prospective application. ${ }^{10}$ In a republic, the legislative power is supposed to be exercised, directly or indirectly, by the people; and power for and by the people is the principal source of direction and legitimacy in a democratic government. For this reason, the legislative power is always, initially, vested in a representative legislature. This legislature typically has the closest political connections to the people themselves, a phenomenon that provides an attractive republican prescription for governmental institutions. Modern constitutions may divide the legislature up in various ways: vertically_by creating a constitutional legislative process, and perhaps by allocating some powers to the legislatures of the provinces or states, and horizontally-by permitting the executive to participate in the legislative process in various ways as a proposer of legislation, a veto player, or both. ${ }^{11}$ Each of these entities-the national legislature, the constitutional legislature, and the provincial legislatures-is a representative institution and, according to standard republican theory, rightly exercises legislative powers.

Second, this article will argue that, although constitutions and public expectations may associate the legislative power with the legislature, that power can and will relocate itself among governmental institutions. From a historical standpoint, it has done so repeatedly. Practically, legislative power shifts around among all the branches of government. So, we see the formal dependence of the executive on the legislature in European systems has had the effect of placing the most substantial legislative powers (the power to propose and to structure the deliberative agenda) in the hands of the government itself. While this trend is less marked in the United States because of the separation of leg-

10. It is not important, for present purposes, to worry about whether courts make or find rules of prospective action. Indeed, on some legislative models, legislative rule-making is epistemic, or ought to be. Whatever courts are doing when establishing rules, they can be regarded as establishing rules that are both prospective and general. This is not to say that there are no differences between legislatures and courts as rule-makers; there are powerful normative reasons why some decisions should be made in one institution, with its attendant procedures, rather than another. Moreover, different institutions will perform differently, and so the allocation of legislative authority is consequential.

11. Obviously, the way in which the executive and the legislature are related differs greatly among democracies, with European governments typically making the executive responsible to parliament. In contrast, the U.S. structure is premised on the notion that the two branches are co-equal (along with the judicial branch). 
islative and executive authority, it is nevertheless apparent. For example, the President has assumed at least informal control over much of the regular legislative agenda (especially when partisan control of government is undivided). And, of course, the gravitation of a great deal of effective legislative authority to courts and executive administrative agencies has become increasingly prevalent in recent years.

I argue that this is not only an empirical fact about political processes, but also a matter guided in part by normative considerations. There are good reasons why some kinds of legislation should be debated and formulated in a legislature, while others should be made in courtrooms or administrative agencies. This is so because different types of substantive legislation seem to require different kinds of reasons or justifications. The best argument for certain policies might be more or less majoritarian: If the people (or their representatives) choose to build a larger or smaller system of national parks, then that decision is, properly, up to them. Other kinds of policies might require appeals to economic, technical, or moral principles. Legislatures often delegate a great deal of authority to insulated central banks and intelligence services, and they also endow myriad other agencies with lawmaking authority in order to ensure that policy is both responsive to technical reason and resistant to political incentives to intervene. And, even if the people would rather not permit some unpopular minority to use public schools or access welfare services, courts require that such legislative proposals respond to considerations of equality and due process. Shifting legislation to courts and agencies, in these respects, has the effect of changing the kinds of considerations - the kind of deliberative justificationsthat go into choosing among policies.

Third, this article argues that, when courts engage in lawmaking, that lawmaking will be responsive to structural political factors. These factors can be modeled explicitly. As a result, a positive theory of judicialization would predict that, under specific political circumstances, courts will be able to make lasting policies. The conditions for policy-active courts are unrelated to the ideological aspirations of political officials. That is, policy-making courts might develop more or less liberal or conservative policies, depending on external structural conditions and the internal makeup of the judiciary. Of course, if positive theorists can explain when courts will assume a policy-making role and what that role is likely to be, then political actors such as judges, bureaucrats, and congressmen will be able to do so as well.

Fourth, I will argue as a corollary that the structural conditions favorable to judicial legislation are also favorable to judicial regulation of the conduct of candidates for office, elected officials, and their appointees. The judicialization of politics has partly the same explanation as the judicialization of lawmaking itself. In this sense, the theory is quite crude and may therefore fail to explain the full extent of judicial regulation of political activity. Perhaps judges play a policing role over politicians even when the structural conditions for judicial policy-making are not propitious. Politicians may, for example, recognize that 
they have a stake in appealing to a more or less independent outside party to enforce rules of fair play. Perhaps this is because it is costly for politicians to try to control corrupt but powerful political leaders. Delegation of regulatory powers to agencies and courts may solve a collective action problem. If these considerations have any bite, my explanation is only partial. ${ }^{12}$

Finally, this article argues that politics-suitably defined and qualifiedtends to follow legislation. I think that this is not only an empirical fact but that it tracks normative considerations as well. Insofar as all of us have a stake in the general rules that govern us, we have claims to influence the formulation and adoption of those rules. This does not mean, however, that the politics of judicial policy-making is the same as legislative politics. Nor does this imply that there is anything wrong with judicial rule-making's having political aspects. Quite the opposite. The power to make rules ought to be the subject of political contestation and deliberation by those whom the rules affect. The shape of judicial politics, however, is and ought to be different in some ways than that which surrounds the political branches.

\section{LEGISLATIVE POWER}

The drafters of the U.S. Constitution shared with Montesquieu the idea that the legislative power could and should be separated from both the executive and especially the judicial power (the power to resolve disputes by applying pre-existing rules). ${ }^{13}$ Montesquieu thought, in particular, that combining legislative and judicial powers in the same hands was the very essence of tyranny-by which he meant arbitrary rule. ${ }^{14}$ In such circumstances, the judge/legislator could simply both shape the rule and decide the case simultaneously. Decisions would be completely unguided by principle and would instead be arbitrary and unpredictable.

Montesquieu worried less about how to establish and maintain the appropriate separation institutionally. He thought that judicial institutions as well the judicial power itself were inherently weak (he called the judicial power a pouvoir nulle, or a null power), and he implied that the real threat of consolidation was to be expected from the holder of legislative power (in his day, presumably, the monarchy). But his exhortations were directed more to the evil than to the remedy. Beyond pointing to English institutions, which he thought had been relatively successful in separating judging from legislating, he provided little guidance as to how such a separation could be developed or sustained.

12. The weakness and dependency of the FEC may be contrary to the idea that these other sources of explanation are particularly powerful. Congress appears to have been careful to keep that agency from developing a capacity to regulate political activity.

13. See Montesquieu, The SpIRIT OF THE LAws ch. 6, bk. 11 (David Wallace Carrithers ed., 1977).

14. $I d$. 
While they rejected other Montesquieuian advice, the framers of the U.S. Constitution adopted this assumption. This is evidenced by the fact that, while the Constitution does establish some institutional restraints on the executive and judicial powers, it is much more concerned about checking and balancing congressional powers. It must have seemed natural in the eighteenth century to think of governmental powers as somehow naturally associated with specific institutional departments. Who else would hold legislative power but the legislature itself? So, for the most part, the framers vested the legislative power in Congress, the executive power in the president, and the judicial power in the Supreme Court. And, since they were concerned that the legislative power was the most voracious and dangerous of governmental powers, what would be more natural than to surround Congress, its nominal holder, with the most substantial institutional checks? As a result, the less dangerous executive and judicial branches were to be monitored only by lesser external checks, at least in the operation of their proper powers. ${ }^{15}$ Of course, the executive and judiciary were made dependent on Congress for funds and delegated authority. ${ }^{16}$ Likewise, appointments to the judiciary, jurisdiction, and enforcement of judicial orders were controlled by other branches. ${ }^{17}$

Today, things do not seem so simple. Lawmaking takes place in every governmental department; only its institutional form differs from one branch to the next. We need not worry much about the fact that some norms take on the particular formal aspect of congressional statutes and are generated according to specific constitutionally governed procedures, while others emanate from administrative processes or from decided legal cases. To the extent that any governmental agency exercises lawmaking power in an unregulated manner, it can be dangerous to liberty.

Twentieth-century legal theorists Hans Kelsen and H.L.A. Hart, in various ways, came to recognize that the identification and control of legislation was a much more complex and open-ended task than it must have seemed in the eighteenth century. Hart, for example, attempted to provide a way of identifying valid legal rules. To this end, he postulated that every legal system can be characterized by a rule of recognition that picks out all valid legal norms. ${ }^{18}$ Such a rule for any proposed norm would have to say whether it constituted a valid legal norm or not-however it emerged and whatever form it took. It would have to, in that respect, recognize norm generation by any institution empowered to do so. Arguments still continue as to the content of Hart's rule of recognition (or, indeed, if that idea is a workable conception of legality), but noone doubts the complexity that such a rule would have to take if it were to track the normative structure of any modern legal system. In particular, it would have to recognize administrative and judicial rule-making as well as rule pro-

\footnotetext{
15. U.S. CONST. art II; art. III.

16. U.S. CONST. art I, §7, cl. 1; art. I, §9, cl. 7.

17. U.S. CONST. art. II, §2, cl. 2.

18. H.L.A. HART, THE CONCEPT OF LAW 92 (1961).
} 
duction by legislatures. Indeed, in the modern state the legislature generates only a tiny minority of the norms by which we live. The rule of recognition, therefore, would mostly amount to an explanation and justification of administrative and judicial action.

From a more practical viewpoint, Kelsen was concerned about keeping legislation under the regulation of superior norms, and to this end he invented the device of an institutionally separated and specialized body to regulate ordinary legislation. ${ }^{19}$ This new court was to be placed outside of the structure of existing governmental institutions and was to be independent of the judiciary as well as of the other branches. ${ }^{20}$ He recognized that this specialized court would itself necessarily be exercising legislative powers of some kind. ${ }^{21}$ At first, he thought that a constitutional court would be engaged only in negative legislation-for example, striking down statutes or ordinances that were inconsistent with constitutional norms-but eventually he was forced to admit that positive legislative powers were in play as well. ${ }^{22}$ After a statute is struck down, it remains to the constitutional tribunal to reconstruct the legal landscape without it, a task that entails the generation of positive norms. More fundamentally, in order to decide whether there is a conflict between a constitutional norm and a statute, a constitutional court must interpret both the statute and the constitutional norm. Such interpretations necessarily specify the extent and shape of the norms and are themselves norm-generating. In this respect, positive norm generation is at the core of constitutional adjudication.

Kelsen's idea for regulating lawmaking, while differing from the U.S. model of judicial review, still places most of its weight on a supreme constitutional body to enforce constitutional norms. Insofar as legislation is produced throughout government, reliance on judicial regulation is likely to be cumbersome and practically inadequate to control the vast quantity of rules that have been produced in the ordinary operation of government. Indeed, modern governments rely more heavily on what we might call "structural methods" for controlling lawmaking. These "structural methods" of regulating legislation can be broken down into three models.

The first model is republican: The production of legislative statutes is controlled principally by the fact that legislators are held accountable to their constituents through elections. Additionally, the participation of the executive is typically required for legislative action and enforcement. ${ }^{23}$

19. Hans Kelsen, Judicial Review of Legislation. A Comparative Study of the Austrian and the American Constitution, 4 J. POL. 183 (1942) (summarizing these ideas in English).

20. Id.

21. Kelsen developed this view in response to criticisms by Carl Schmitt in HANS KeLSEN, WER SOLL DER HUETER DER VERFASSUNG SEIN (WHO IS TO BE GUARDIAN OF THE CONSTITUTION) (1931).

22. $I d$.

23. This dependence on the executive branch is constitutionally explicit in presidential systems such as in the United States, where the president has a limited veto. In parliamentary systems, such as that in Great Britain, Germany, Italy and France, however, the executive typically monopolizes access to the legislative process. 
The second model is of more recent vintage: Administrative rule-making is controlled by the agency's dependence on the legislature for funding and authority, by the agency's dependence on the executive for staffing and direction, and by procedural requirements on rule-making. So, administrative legislation is controlled indirectly by the fact that administrators are responsible to elected officials.

The third model illustrates that the control of judicial legislation is largely managed by limits on courts' jurisdiction. ${ }^{24}$ U.S. federal courts, for example, may only decide cases or controversies between actual parties who are in genuine conflict with one another. ${ }^{25}$ Moreover, whatever general norms are formulated in order to frame and settle a particular dispute are to have legal effect only on those future cases that are sufficiently similar to the original dispute. In addition, courts, like agencies, are dependent on the legislature for funds and authority, and on the executive for enforcing judicial orders.

Judicial legislation is, therefore-at least in principle-limited in its reach. These limits are reinforced by the limitations on what counts as precedent. Moreover, courts sometimes adopt a policy of deferring to elected or appointed officials or administrative departments. An example is the Chevron doctrine, ${ }^{26}$ which commits courts to defer to agency interpretations of their own statutes so long as those readings are textually plausible. ${ }^{27}$ But it is important to see that the limitations on lawmaking with respect to judges are, unlike those on the other departments, self-imposed. These limitations arise from judicially developed and judicially enforced ideas of justiciability, precedent, and whatever policies of deference to other governmental departments courts have decided to follow.

\section{III}

\section{THE POLITICS OF LAWMAKING}

Classical democratic theory associates politics with the activities of the legislature, and law with the operation of the judicial branch. Politics is natural to the operation of the legislature and is both unavoidable and legitimate there. Indeed, political contestation is understood as necessary to realize core democratic values. The legislature makes laws that are binding on all; each individual, therefore, has a stake in deciding who should sit in the legislature. All are entitled to monitor legislative debates, to have timely input and influence on their decisions, and to demand that its members stand before us to account for what they have done in elections. These political expectations entitle us to or-

24. In U.S. federal courts, these limits take the form of justiciability doctrines that are developed by the courts to police themselves. We argue here that these doctrines evolve under the shadow of possible congressional regulation. See John Ferejohn \& Larry D. Kramer, Independent Judges, Dependent Judiciary: Institutionalizing Judicial Restraint, 76 NYU L. REV. (forthcoming 2002).

25. U.S. CONST. art. III, § 2, cl. 1.

26. Chevron U.S.A. v. Natural Resources Def. Council, 467 U.S. 837 (1984).

27. Id. at 843 . 
ganize parties and factions to elect, monitor, criticize, oppose, and otherwise influence lawmakers. In this sense, lawmaking politics is expected to be contentious, partisan, and ideological. To be sure, the political space to criticize and contest power can be abused in ways that threaten the operation of democracy itself. Madison insisted that the spirit of faction can be dangerous to liberty and therefore, ultimately, to democracy. ${ }^{28}$ He also recognized, however, that in a republic, factions and parties, which serve to further both public and private interests, cannot be abolished without undermining republican government itself. At best, the politics of faction and party can be regulated or managed to limit the likely abuses. The most satisfactory form of regulation relies on the electoral process to correct political pathology. Of course, if democratic selfregulation fails, there are court-enforced constitutional safeguards that may be employed to limit abusive lawmaking.

By contrast, law, or the application of law, is supposed to happen in courtrooms. The application of law may be controversial, but it is expected to be mostly a technical matter of finding the right principles under which the dispute can be settled. The duty of judges and legal officers is to provide fair and unbiased tribunals before which conflicting parties can settle their disputes under pre-existing accepted legal norms. This model sees courts as places where particular disputes are settled, not as places where general and prospective regulations are formulated. Citizens have no legitimate claim to influence courts as they do the legislature, or at least not in the same ways that they seek to influence the legislature. They can enact statutes indirectly by lobbying legislatures, and they can try to assure that competent and sympathetic judges are appointed to the bench by lobbying those officials responsible for political appointments. Perhaps citizens can even demand that judges stand for election from time to time. But citizens have no claim to overturn judicial rulings or to press judges to decide ongoing cases in one way or another. And, even where judges are subject to elections, there is more than a little squeamishness about the idea that they should have to run electoral campaigns, or make promises as to how they will decide future cases. ${ }^{29}$ The two activities-legislative and judicial-are to be conducted separately, according to different principles. In courtrooms, there is no place for partisan activities, no room for pressuring or influencing judges to make particular decisions, and only a little room to eject poorly performing judges from the bench.

Nowadays the notion that politics can or ought to be confined to the legislative process is recognized as too simplistic. No one doubts that administrative, or delegated, lawmaking can have consequences that reach as widely as ordinary congressional acts. ${ }^{30}$ The role of administrative agencies in creating af-

28. THE FEDERALIST 10, 51 (Madison).

29. See Steven P. Croley, The Majoritarian Difficulty: Elective Judiciaries and the Rule of Law, 62 U. CHI. L. REV. 689 (1995).

30. See, e.g., Cornelius Kerwin, Rulemaking: How Government Agencies Write Law AND MAKE POLICY (2d ed. 1999). (From the 1970s on, "to a remarkable extent the health, safety, financial well-being, and general quality of life of Americans would hinge on the success of rulemaking 
firmative action policies, vehicle emissions rules, requirements for the disposal of hazardous wastes, prescription drug regulation, the identification of endangered species, and the development of regulations on logging on federal lands all illustrate the wide extent of delegated lawmaking. Rule-making in each of these areas involves substantial redistributions of wealth and picking winners and losers. As a consequence, each situation is inherently controversial and often hard-fought. Not surprisingly, those persons who are to be subject to the rules are often willing to spend substantial resources, directly and indirectly, to influence the form regulations are to take. ${ }^{31}$ Sometimes interest groups work to shape the proposed rule within the rule-making process. Sometimes groups work to influence who is appointed to policy-making positions within the agency. And of course, sometimes, interest groups work to elect congressional and presidential candidates, who will in turn appoint sympathetic people to the administrative posts. ${ }^{32}$ In the case of administrative agencies, citizens expect that interest groups subject to agency rules will try to influence, one way or another, what those rules are. And sometimes this will lead these groups to engage in partisan activity-favoring one party's candidate over another-and sometimes it will lead them to seek access to officials affiliated with both of the major parties. In this sense, administrative lawmaking is inevitably and justifiably politicized.

If anything, the consequences of judicial rule-making are often more profound than agency policy-making. The familiar cases to which we can point include the countermajoritarian confrontations such as the 1937 standoff between the Supreme Court and the New Deal congresses. ${ }^{33}$ The New Deal congresses asserted legislative authority over the economy that contravened various judicial doctrines and, in the end, the Supreme Court was induced to reshape those doctrines. ${ }^{34}$ Negative instances, where courts successfully block ordinary legislation on the ground that it infringes some fundamental right, are most familiar to students of constitutional law in cases such as Planned Parenthood v. Casey. There, the court refused to permit certain legislative restrictions on access to abortions. $^{36}$

Judicial legislation is not always, or even primarily, "negative" in the sense of preventing legislative majorities from acting as it decides best. Judges also make law in a more positive sense-acting where the legislature has refrained from doing so. The famous instances include the extension of constitutional

by agencies. These rules would also impose unprecedented costs, transfer huge amounts of wealth across our society and affect our capacity to vie in increasingly competitive world markets.")

31. JAMES WILSON, THE POLITICS OF REGULATION (1980).

32. James Wilson, Bureaucracy: What Government Agencies Do And Why They Do IT (2000).

33. Barry Friedman, The History of the Countermajoritarian Difficulty, Part Three: The Lesson of Lochner, 76 NYU L. REV. 1383, 1396 (2001).

34. Id.

35. 505 U.S. 833 (1992).

36. $I d$. 
protections to those accused of crimes,${ }^{37}$ the development of rights to abortion, ${ }^{38}$ the development of policies to integrate the schools ${ }^{39}$ or establishing busing plans in various school districts, ${ }^{40}$ the development of rules governing prayer in the schools, ${ }^{41}$ and many others. Nothing in any of these policy areas made them uniquely fitted for judicial rather than legislative determination. Courts acted partly because legislatures could not act, or if they did, acted inappropriately.

In each of these cases, courts developed policies that had far-reaching and quite direct political ramifications. Politicians sometimes responded by organizing campaigns to impeach sitting justices, and some have tried to develop new legislation aimed at testing and narrowing the reach of judicial doctrines, as in Casey, where the Pennsylvania legislature tried to erode the protections granted in Roe. $^{42}$ Most frequently, the political response has been to try to influence the composition of the courts in the appointment process. Sometimes these attempts involve mobilizing public opinion, organizing demonstrations, and encouraging resistance. Most often, however, court-made policies have become thematic material for electoral campaigns. ${ }^{43}$ Democrats have been vilified for appointing justices favorable to protecting the criminally accused, or rights to abortion or family planning services." Since Nixon's adoption of the "Southern Strategy" in 1968, Republicans have sometimes campaigned against the Supreme Court almost as much as against Democrats. ${ }^{45}$ Indeed, one could argue that reactions to court-developed policies in civil rights and criminal procedure have done as much to shape the development of American electoral and congressional politics since 1968 as have any congressional decisions.

These examples illustrate that politics, often contentious partisan politics, is inevitably associated with the exercise of legislative power, and that courts are not immune to these pressures. Whenever general and prospective rules are made, there can be disagreement as to what the content of such rules ought to be, and the resolution of this disagreement cannot be confined to settling the dispute between the litigating parties. The contest among these competing ideas is intrinsically political in the sense that the choice of one rule or interpretation over another must be justifiable in some sense to those whom the rule affects. Judicial argument is never expressed in partisan terms, but arguments over which rules should be adopted are nonetheless political. These arguments

37. Miranda v. Arizona, 384 U.S. 436 (1966); Mapp v. Ohio, 367 U.S. 643 (1961).

38. Roe v. Wade, 410 U.S. 113 (1973).

39. Brown v. Board of Education, 347 U.S. 483 (1954).

40. Swann v. Charlotte-Mecklenburg Bd. of Ed., 402 U.S. 1 (1971).

41. Santa Fe Independent School District v. Doe, 530 U.S. 290 (2000); Lee v. Weisman, 505 U.S. 577 (1992); Wallace v. Jaffree, 472 U.S. 38 (1985).

42. Planned Parenthood of Southeastern Pennsylvania v. Casey, 505 U.S. 833, 844 (1992); Roe, 410 U.S. 113.

43. Thomas Edsall And MARy Edsall, Chain REACTION 19, 114 (1991) (describing the Willie Horton ads, which blamed crime on permissive judges).

44. Id.

45. Id.; see also KEVIN PHILliPS, THE EMERGING REPUBLICAN MAJORITY (1969) (an early and prescient articulation of this strategy). 
concern the way that legal texts and previous decisions are to be understood, or about what the constitution, or some conception of justice, requires. However they are phrased, these disputes are about within what rules citizens should live, and everyone has a stake in seeing how they are decided.

The people have a rightful stake in lawmaking, wherever it occurs. That stake is most obvious for legislatures and is often articulated in theories of administrative law as well. One reason that such agencies can legitimately make law is that there is a chain of accountability extending to elected officials such as the President and members of the Senate. Insofar as that chain is regarded as too long or too indirect, agency accountability may be enhanced by requiring that rule-making conform to additional procedural requirements, ensuring notice, and providing open access to anyone with interests in the proposed rules. Of course, these quasi-democratic justifications are not the only justifications for agency lawmaking. Taking advantage of technical expertise, getting good information, and perhaps incorporating professional norms in formulating policies might provide stronger defenses in many cases.

In the case of judicial rule-making, popular justification, however indirect, is harder to come by. Some legal scholars emphasize that courts have a popular pedigree, and appointments to high courts sometimes conform to representational norms. ${ }^{46}$ However, while citizens may be comfortable with politicians appointing judges, they are not usually willing to make judges accountable to elected officials for their actions on the bench-not unless those actions are impeachable. Even where there are judicial elections, these events tend to be lowinformation affairs favorable to returning the incumbent, and are seldom organized according in a partisan manner that might encourage the electorate to play a real role in choosing judges. ${ }^{47}$ Indeed, as the early opponents of the Constitution recognized, the insulation of courts from political processes poses special problems of control, especially insofar as courts are producing legislation. ${ }^{48}$

Moreover, a better account of the legislative role of courts in a democratic society would emphasize that the legimacy of judicial lawmaking is based on its deliberative character. On this view, the characteristic feature of the judicial legislative process arises from the weakness of its democratic credentials. ${ }^{49}$ Courts, unlike legislatures, are expected to engage in a deliberative process to

46. Chris Eisgruber, CONSTITUTIONAL SELF GOVERNMENT (2001).

47. There is a substantial amount of literature in political science that argues that voters are able to make intelligent choices in low-information elections, at least where such elections are competitive. See the essays in ELEMENTS OF REASON (Arthur Lupia, Matthew McCubbins and Samuel Popkin eds., 2000), in particular the concluding essay, Arthur Lupia et al., Constructing a Theory of Reasoning, id. at 287.

48. This was one of the themes of the Anti-Federalist attack on the Constitution. See SAUL CORNELl, THE OTHER Founders: ANTI-FEDERALISM AND THE DisSENTING TRADITION IN AMERICA, 1788-1828, 90-91 (1999). Writings of Anti-Federalists such as Federal Farmer, Brutus, Elbridge Gerry, George Mason, and others reflecting this theme have been collected in a seven-volume work, THE COMPLETE ANTI-FEDERALIST (Herbert J. Storing ed., 1981).

49. John Ferejohn \& Pasquale Pasquino, Deliberative Institutions, in Constitutional JusticE, EAST AND WEST (W. Sadurski ed., forthcoming 2002). 
find or shape general rules. Specifically, at least at the appellate level where such rule-making occurs most explicitly, courts are to offer reasoned justifications both for their decisions and for doctrinal changes. Insofar as courts are expected to give reasons, they are accountable for their decisions. They are not, of course, accountable in the same way that elected officials are. A poorly reasoned decision will not get a judge removed from the bench. But the finality of that decision-whether it will be appealed and overturned-and the reach of the decision through whatever rules that decision was intended to establish, may be limited by other judges, lawyers, or by elected officials. Poorly justified decisions tend not to have extensive impact.

By way of contrast, citizens do not expect very much in the way of reasongiving from legislatures, at least not as a condition for regarding statutes as binding. If a congressman can put together a large enough political coalition to enact a statute-whether by convincing other members or by trading votesthat statute has a claim on our obedience and respect. Additional reasons are not required. Those of us who do not like the policy can electioneer and campaign replace the congress, or terrify it, and get the statute changed. In this sense, members of the legislature are personally accountable for their actions.

While the model of a popularly accountable legislature has a certain austere elegance, it does not take account of the complexity of making good rules. Lawmaking is inherently fraught with uncertainties in that no one can know what the consequences of a newly adopted rule will be. It is hoped, of course, that the legislature will adopt internal institutions and practices that manage this uncertainty intelligently. Indeed, in the United States, Congress has adopted a complex committee system with extensive professional staff, and members of Congress have often become substantive policy specialists. ${ }^{50}$ Congressmen have learned as well to draw upon the expertise of broad networks of specialists both in government and in the private sector to help in the lawmaking enterprise. ${ }^{51}$ In other countries, the government, which is a particularly powerful committee of the legislature, marshals the resources of the executive departments to manage legislative uncertainty. ${ }^{52}$ But no matter how or how well it is managed, one can never fully anticipate the effects of prospective rules.

The delegation of authority to specialized administrative agencies is a partial response to this lawmaking uncertainty. Rather than trying to anticipate all the complexity to which a general rule would need to respond, Congress authorizes administrators to develop more detailed rules, and it encourages them to gather additional evidence and employ specialized expertise. ${ }^{53}$ Presumably, the growth

50. RICHARD FENNO, CONGRESSMEN IN COMMITTEES (1973).

51. Steven S. SMith, THE AMERICAN CONGRESS 109-11 (1995) (describing expanded resources available to members of Congress).

52. Michael LAVER \& KenNeth Shepsle, Making AND BREAKing Governments: CABINETS AND LEGISLATURES IN PARLIAMENTARY DEMOCRACIES 3 (1996).

53. D. RODERICK KieWIET \& MATHEW D. MCCubbins, THE LOGIC OF Delegation: CONGRESSIONAL PARTIES AND THE APPROPRIATIONS PROCESS (1991); DAVID EPSTEIN \& SHARYN 
and permanence of the administrative state testifies to its effectiveness in developing finer-grained rules than Congress could manage by itself. Still, administrative rule-making tends to be a fairly rigid and costly enterprise; rules are adopted in these agencies, as in Congress, largely through anticipating how these rules will alter behavior in the future..$^{54}$ True, agencies sometimes can respond to individual cases and tailor the application of rules in some ways. Without a norm of stare decisis, however, case-by-case decision-making is ineffective in altering the rules themselves.

In view of the intractable uncertainty of prospective lawmaking in agencies as well as Congress, courts possess some unique advantages. Courts consider rules in light of specific particular circumstances and are well-positioned to see the injustices and inconveniences they impose on various litigants. While the rules courts develop are prospective, standing as precedents for similar cases in the future, the resolution of the case before them is not. Moreover, the practice of stare decisis permits the gradual development of general rules through the activities of many courts and judges and cases. ${ }^{55}$ As common lawyers have argued for centuries, this kind of experience can help to shape rules that are well-suited to actual circumstances of interaction.

\section{IV}

\section{EXPLAINING JUDICIALIZATION}

I shall explore two general causes of judicialization. The first is an increasing fragmentation of power within the political branches which limits their capacity to legislate, or to be the place where policy is effectively formulated. ${ }^{56} \mathrm{I}$ shall call this the fragmentation hypothesis. When the political branches cannot act, people seeking resolution to conflicts will tend to gravitate to institutions from which they can get solutions; courts (and associated legal processes) often offer such venues. At least in the United States, with its system of checked legislative powers, a divided legislature cannot easily stop courts from making policy-even quite unpopular policies.

The second cause is more nebulous but perhaps more important. It is the sense that courts (at least certain courts) can be trusted to protect a wide range of important values against potential political abuse. Let us call this the rights hypothesis. The idea is that, as courts began to protect personal rights and liberties in addition to property rights, opposition to an expansive judicial role diminished. In the United States this shift from protecting economic to personal liberties and civil rights was announced by the Supreme Court in Carolene

O'Halloran, Delegating Powers: A Transaction Cost Politics Approach to Policy MAKING UNDER SEPARATE POWERS (1999).

54. EPSTEIN \& O'HALLORAN, supra note 53.

55. John Paul Stevens, "The Life Span of a Judge Made Rule," in ThE Evolving Constitution (Norman Dorsen ed., 1987).

56. See Jenna Bednar et al., A Political Theory of Federalism, in COnSTITUTIOnAl Culture AND DEMOCRATIC RULE 223-67 (John Ferejohn et al. eds., 2001). 
Products. $^{57}$ In postwar Europe, the shift awaited the development of new courts - constitutional tribunals - which were charged explicitly with the protection of a wide range of human rights. ${ }^{58}$ In both cases, the encouragement of a jurisprudence that offered protection for a wide range of human rights and values, and the growth of courts capable of breathing life into these values, was partly due to the people and to their legislatures.

These two hypotheses can be evaluated with either domestic or comparative information. Take, for example, the hypothesis that judicialization is explained by the increased capacity or willingness of courts to protect wider collections of rights. A puzzling aspect of the sudden postwar rise of constitutional courts in Europe is the collapse of historically powerful left and left-of-center opposition to judicial review. Judicial review was seen by these parties as antimajoritarian and, based on the American example, European left parties saw it as a thinly veiled attempt to entrench property rights. ${ }^{59}$ After World War II, this opposition was again voiced in both France and Italy from the left but, at least in Italy, that opposition failed to prevent the establishment of a constitutional court. ${ }^{60}$ The impact of this failure is perhaps sharpened when it is recalled that the left, especially the Communist Party, was at its peak of popularity in the immediate post-war period. If leftist parties had been able to block constitutional courts before the war, why could they not continue to do so in a circumstance where virtually all other political forces had been compromised or discredited?

In another article, Pasquale Pasquino and I have argued that the expansion of the set of rights to be protected by the proposed constitutional courts played an important role in the rapid and widespread acceptance of constitutional adjudication in Italy and elsewhere in Europe. ${ }^{61}$ The need to ensure that ordinary lawmaking would be regulated by fundamental values was especially urgently felt in Italy and Germany: The ordinary lawmaking processes in those countries had completely failed to respect human rights during the fascist and nazi periods. Not only was the legislature suspect as a defender of fundamental rights, so too were the ordinary courts, which had done little to control or limit the impact of authoritarian legislation. ${ }^{62}$ The institution of new constitutional courts, which would have the power to overturn legislation but be independent from

57. 323 U.S. 18 (1944).

58. Ferejohn \& Pasquino, supra note 49.

59. The leader of the Italian Communist party articulated this objection during the debate over the creation of a constitutional court in the Constituent Assembly in 1947: "All of this is inspired by fear: the fear that tomorrow there might be a majority that is the free and direct expression of those working classes that want to remake profoundly the political, economic, and social structure of the country; and against this eventuality they want to have guarantees and to place impediments: from this we get the heaviness and slowness of the legislative procedure ... from this we get that bizarre creature the Constitutional Court." Michael Mandel, Legal Politics Italian Style, in Tate \& Vallinder, supra note 4, at 265.

60. Id. at $265-70$.

61. Ferejohn \& Pasquino, supra note 49.

62. Michael Mandel argues that "The initial activity of the [Italian] court . . . was the dismantling of the fascist legal order ...." Legal Politics Italian Style, in Tate \& Vallinder, supra note 4, at 267. The same thing could be said about the initial task of the German constitutional court. 
the judiciary itself, were part of a response to this double circumstance of distrust-of the legislature and of the ordinary court system. ${ }^{63}$ But how could opponents of judicial review be persuaded that a specialized constitutional court could be relied upon to protect a wide range of human rights and not only rights of property? Our suggestion is that, by making appointments to it in a manner that permitted both left and right parties a role in appointments, and by insulating the new courts from the ordinary judiciary, the proposed constitutional courts became more credible as enforcers of human rights. ${ }^{64}$

The rights hypothesis can be evaluated with U.S. materials as well. The standard story about the pre-New Deal court was that it tended to enforce a version of the Constitution that was heavily tilted toward protecting propertyrelated interests. ${ }^{65}$ Given the record of the Supreme Court in this period, it is not surprising that there was significant opposition from liberals to the institution and practice of judicial review. ${ }^{66}$ But, however one interprets the events of 1935 to 1937 , by 1940 the Court had begun to protect a very different mix of rights; indeed, it entertained and enforced a different theory of the Constitution altogether. ${ }^{67}$ Part of the reason for this was a dramatic change in the membership of the Court. Roosevelt's new appointees had both personal and political commitments to defining and protecting other, non-property-related interests. ${ }^{68}$ Faced with this new and very different Supreme Court, it is not surprising that systematic left opposition to judicial review began to erode and that, indeed, political liberals have come to form the principal support for the Court's new jurisprudence. ${ }^{69}$

The fragmentation hypothesis can also be tested either locally, with information on U.S. political history, or in a broader, comparative setting. Here, the idea is that courts can exercise independent authority to shape policy only when political institutions are too fragmented to check them. ${ }^{70}$ Political fragmentation is a complex idea that can arise in many different ways. Federalism, for example, fragments certain kinds of political powers-vertically, between central and local governments-and can create the space for judicial action. Federal sys-

63. Ferejohn and Pasquino, supra note 49.

64. STONE SwEET, supra note 1, at 47 tbl.2.2 (describing modes of appointment of justices in various constitutional courts).

65. See Friedman, supra note 33, at 1389-1402 (providing a careful history of standard and revisionist accounts of Lochner).

66. Indeed, it is not surprising that European observers of American judicial review concluded that such review would only protect property rights. See supra note 59.

67. This shift was signaled by Justice Harlan Stone's famous "footnote four." U.S. v. Carolene Products Co., 304 U.S. 144, 153 n.4 (1938) (suggesting that discrimination against "discrete and insular minorities" might warrant heightened judicial scrutiny).

68. Alpheus Mason, The Supreme Court From TAFT to Burger 157-60 (1979).

69. E.g., RonAld DWORKIN, A MATTER OF PRINCIPLE 316-31 (1983) (defending Justice Brennan's opinion in United Steelworkers of America v. Weber, 443 U.S. 193 (1979)).

70. Bednar et al., supra note 56, at 262 (" $[\mathrm{I}] \mathrm{t}$ is important to see that the restraints on the federal government work only so long as no cohesive and long-lived majority is formed. If such a majority were to appear and was determined to undermine state authority, the structural protections could probably not resist it for very long."). 
tems not only provide opportunities and duties for states to make policy unchecked by the national government, they also generally provide the states with the capacity to block or slow actions by the national government. Finally, jurisdictional disputes in federal systems, whether between states or between a state and the national government, need to be resolved, and courts are typically employed for this purpose.

Federalism is, of course, only one way that formal institutions can instantiate fragmentation. Another is by dividing powers horizontally, by adopting a presidential form of government. In presidential systems, the executive is not accountable to the legislature but responds to the electorate more or less directly. The executive is a coordinate branch of government with the same constitutional status as the legislative and judicial departments. Presidential systems usually provide means by which the different branches may check the others in the exercise of their proper functions. Presidents typically have some kind of veto authority, legislatures usually control budgetary authority, and courts need executive and sometimes legislative action to enforce their orders. Checks of this kind tend to produce circumstances of stalemate and crisis. ${ }^{71}$ Institutionally, then, power tends to be more fragmented in presidential than in parliamentary systems.

Institutional fragmentation can be overcome if the political parties are sufficiently well-organized and self-disciplined. Well-organized parties can coordinate actions across institutions, at least in some circumstances. The clearest examples of this are not very attractive. Until recently, the two examples were found in one-party systems with "Leninist" parties such as those found in the former Soviet Union or in Mexico. There are less extreme circumstances in which relatively well-organized parties can overcome institutional entropy. Western European political parties are usually quite disciplined as well, but they do not typically obtain parliamentary majorities. The best known exception, however, is the British Westminster model, in which one party usually attains a majority of seats in the House of Commons and maintains tight discipline in parliamentary votes. Such discipline makes the executive responsible to the House of Commons; if the government loses its majority support in the lower chamber, it is required to resign. The fact that one party nearly always has a majority and can discipline its members permits the British to maintain a system of governmental responsibility. In effect, legislative power is never fragmented in Britain. ${ }^{72}$

71. Bruce Ackerman, The New Separation of Powers, 113 HARV. L. REV. 633, 645-48 (2000) (describing the tendency of presidential systems to come to an impasse, and citing the work of Juan Linz documenting impasse tendencies of South American democracies that have used the presidential model).

72. This is, of course, an overstatement. During the 1970 's, the Labour party was so unable to maintain internal party discipline that it actually refused to act according to the constitutional norm requiring the government to resign if it could not enact critical legislation. SAMUEL H. BEER, MODERN BRITISH POLITICS: A STUDY OF PARTIES AND PRESSURE GROUPS (1982). 
Fragmentation can also be achieved in less institutional ways. For example, divided government systems feature separate parties or coalitions that control different branches. In presidential systems, a typical form of divided government has one party controlling the legislature and the other controlling the presidency. By contrast, in parliamentary systems, divided government occurs when control over the two legislative chambers is split. By making coordinated legislative responses difficult, either form of government provides room for courts to make policy unchecked. Observers of divided government often describe it as something that just happens-like the weather-and not something that the electorate brings about intentionally. Recent scholarship in this area suggests that a substantial, and pivotal, fraction of the electorate may be advantaged by dividing governmental powers and that they may even intentionally split their ballots in order to bring about such a system. ${ }^{73}$

The U.S. system, on the other hand, is more complex. One reason is that, in the United States, parties usually cannot manage to discipline themselves very effectively. This is partly due to an electoral system that makes each member of Congress a kind of ambassador from his or her district or state, and partly due to the fact that the President is separately elected. Representatives in such a system are given every motivation to respond to the diverse needs of their constituencies rather than to band together behind a coherent party program. Circumstances in which a majority party is able to coordinate and discipline its legislative activities tend to be quite brief. Roosevelt's first or second hundred days, Lyndon B. Johnson's Eighty-Ninth Congress, and perhaps Newt Gingrich's Contract with America in the first term of the 104th Congress provide examples. In each of these cases, a majority party was sufficiently unified with respect to specific achievements that the endemic parochialism of U.S. electoral and constitutional institutions was temporarily subdued. ${ }^{74}$ This parochialism, of course, can be overcome sometimes in periods of war, emergency, and economic crisis. The real lesson of these examples, however, is how rare and brief the periods of unified parties actually are.

The fragmentation hypothesis implies that courts have more freedom of action when the political branches are too fragmented to make decisions effectively. In such cases, policy making tends to gravitate to institutions that can resolve disputes effectively. This claim needs to be qualified a bit from the start. I am assuming that courts will tend to exercise their authority within political constraints. That is, they will not adopt courses of action that lead to regular and repeated reversals or other sharp reactions by the political branches; doing so would generally lead to inferior outcomes from the perspective of the judges and would also diminish any routine deference that they may enjoy from the other branches. If this hypothesis holds, then we would expect increases in

73. E.g. MORRIS FIORINA, DIVIDED GOVERnMENT 60-85 (1992).

74. See Bednar et al., supra note 56, at 256-62 (discussing importance of fragmentation as crucial to judicial role, and describing the Civil War and Reconstruction, Roosevelt's first term, and the Johnson Great Society as brief instances in which political consensus replaced fragmentation). 
fragmentation to lead to wider areas of policy in which courts can determine outcomes, without risking overrides from political officials. Obviously, if courts attempt to fix policy outside these bounds, political institutions would be capable of intervening.

Now we can consider some other comparative cases. The most striking, no doubt, is the development of European legal institutions since the Treaties of Rome and Paris. ${ }^{75}$ European political institutions have been a textbook instance of fragmentation. They combine a federal structure with extremely indecisive political institutions that are required to make decisions by employing either unanimity rule or qualified majority rule. ${ }^{76}$ Moreover, there is no Europeanwide party system - the parties are organized at the national level and are internally heterogeneous in the same way as U.S. parties. This institutional structure-which is sometimes said to create a "democratic deficit"-resembles nothing so much as the Articles of Confederation.

In this context, the European bureaucratic and judicial institutions have flourished. The European Commission has been accorded a very wide latitude for formulating policy initiatives and establishing binding regulations with little fear of checks from either the national governments or the European Parliament. The European Court of Justice ("ECJ") has been just as effective in establishing jurisdiction over national laws or ordinances that affect the movement of goods, finance, or people throughout the European Union ("EU"). Not surprisingly from this perspective, much of the development of the European Common market, and indeed of European social and economic integration, has been guided by the Commission and the Court of Justice rather than by the Parliament or the national governments. ${ }^{77}$ This is, however, not to deny that European bureaucrats have wide freedom to maneuver as well.

The fragmentation of European institutions may have diminished somewhat in recent years-especially since the ratification of the Single European Act in 1986 and the Maastricht Treaty in 1992. ${ }^{78}$ These new agreements introduced and expanded the use of qualified majority rule. Moreover, the European Parliament has been able to assume a marginally more significant role in proposing legislation and in budgetary decision-making. Over the same period, however, the introduction of new member states on the European fringe has increased the internal heterogeneity of the EU, and this would tend to increase fragmentation. So, at the present time, it is unclear whether the decision-making latitude of the ECJ is increasing or decreasing. What is clear is that, when compared with the circumstance of any of the national judicial institutions, the ECJ has an extremely wide area for judicial discretion.

75. STONE SWEET, supra note 1 , at ch 6.

76. $I d$.

77. Andrew Moravcsik, The Choice for Europe: Social Purpose and State Power FROM MESSINA TO MAASTRICHT (1998).

78. Jenna Bednar et al., Politics of European Federalism, in 16 INTERNATIONAL REVIEW OF LAW AND ECONOMICS (1996). 


\section{$\mathrm{V}$ \\ JUDiCIAL REGULATION OF POLITICS}

The direct regulation of political activity is an especially important and increasingly common form of judicialization. When elected officials see that bench appointees may become their regulators, prosecutors, and jailors, the stakes of judicial appointment ratchet to a higher level. Courts historically have been heavily involved in regulating political activities, often employing racketeering and mail fraud statutes to draw and police the boundaries between acceptable and corrupt political practices. Over the course of the last halfcentury, judges and prosecutors have outlawed venerable political practices that had arguably been at the foundation of political parties since the early years of the republic. ${ }^{79}$ These efforts have often been controversial and certainly have not always impacted political parties or public officials evenly. ${ }^{80}$ Outlawed practices have forced some high-ranking incumbent office-holders from office and into prison. ${ }^{81}$ At times, judicial regulation has advantaged one or the other major party or screened the established parties from competition. In any case, it is certain that judicial scrutiny of political parties and politicians has played a significant role (along with other statutory reforms) in altering the ways that they develop and seek votes.

Recent legal regulation of democratic practices has focused on developing constitutional doctrines that permit courts to reshape political practices. Apportionment, access to the ballot box, campaign finance, and other modes of regulating political life, long shielded from judicial scrutiny by the political question doctrine, came under increasing pressure in the post-World War II period. ${ }^{82}$ The post-Civil War amendments have played an especially important role in these developments by permitting more congressional and judicial regulation of state political practices. However, while Congress has sometimes used its enhanced authority under these Amendments to put in place legislation aimed at opening up the political process to previously excluded groups, much of the important action has taken place in agencies and courts. As in the case with the fraud statutes, court-imposed constitutional restrictions on political practices have had an uneven impact on democratic processes. Sometimes courts have disadvantaged entrenched political parties by denying them control

79. See, e.g., Shakman v. Democratic Org. of Cook County, 481 F. Supp. 1315 (N.D. Ill. 1979) (outlawing the hiring of governmental employees on the basis of political affiliation, sponsorship, and support).

80. Note that the Nassau County Republican machine was the target of federal prosecutors in United States v. Margiotta, 688 F.2d 108, 121 (2d Cir.1982), cert. denied, 461 U.S. 913 (1983).

81. U.S. v. Rostenkowski, 59 F.3d 1291 (D.C. Cir. 1995) (former Illinois Congressman convicted of misappropriation of government funds).

82. See, e.g., Baker v. Carr, 369 U.S. 186 (1962) (claim that apportionment statute violated equal protection upheld as judicable and within scope of Fourteenth Amendment); Buckley v. Valeo, 424 U.S. 1 (1976) (campaign finance law scrutinized and codified). 
over nominations or altering the franchise and redrawing district boundaries. ${ }^{83}$ Other times, judicial regulation has worked to protect incumbents or has established parties at the expense of newcomers. ${ }^{84}$

Of course, newly robust constitutional restrictions have not always worked to pry open the political process to include previously excluded minorities. The development of increasingly robust First Amendment rights of speech and association in the last quarter century has limited the capacity of the people or their representatives to regulate campaign finance or to reform parties or the party system. ${ }^{85}$ This line of constitutional development has led the court to a series of rulings broadly favorable to incumbent parties and officials.

The most striking recent development, however, is the increasing willingness of the Court to impose what might be called "deliberative requirements" on legislatures. This tendency is most pronounced in the recent series of federalism decisions. ${ }^{86}$ In each of these cases, the court demanded that Congress provide a reasoned justification for its authority to enact certain statutes. ${ }^{87}$ Furthermore, the Court appears to have set an increasingly high bar for what will count as an adequate justification for the exercise of Commerce Clause or Section 5 authority. As others have noted, the Court seems to be treating the legislature in this respect as it would an agency or even an inferior court. ${ }^{88}$

Naturally, we have no idea how far this practice will extend, but from the standpoint of this article, its potential reach is of special significance. Even if the court leaves undisturbed an exercise of legislative authority, the demand that such authority be connected to adequate reasons would have the effect of forcing the legislature to act like a court when enacting statutes. Maybe this is a good idea, especially in statutes imposing particular burdens on protected liberties. But to demand that a majority act reasonably in all cases is to deny it a capacity to govern and to be democratically responsible before the people for governing. In this respect, the imposition of deliberation requirements poses separation of powers issues.

While this observation is not original (and may turn out to be exaggerated), it is connected to the larger claim of this paper. The Court's willingness to impose increasing constitutional restrictions on legislatures can be explained in terms of its increasing political independence of the other branches. The court

83. Note the role of courts in dismantling Democratic control of southern politics by giving effect to the provisions of the Voting Rights Act and subsequent amendments. See generally Samuel Issacharoff, Supreme Court Destabilization of Single Member Districts, 1995 U. CHI. LEGAL F. 205.

84. Samuel Issacharoff \& Richard Pildes, Politics as Markets, 50 StAN. L. REV. 643 (1998).

85. See, e.g., California Democratic Party v. Jones, 530 U.S. 567 (2000); Tashjian v. Republican Party of Connecticut, 479 U.S. 208 (1986) (state law mandating closed primary held invalid); Democratic Party of the United States v. Wisconsin, 450 U.S. 107 (1981) (state law mandating open primary held invalid); Buckley v. Valeo, 424 U.S. 1 (1976) (certain provisions of the federal law regulating campaign contributions and spending held invalid).

86. Bd. of Tr. of Univ. Alabama v. Garrett, 531 U.S. 356 (2001); United States v. Morrison, 529 U.S. 598 (2000); United States v. Lopez, 514 U.S. 549 (1995).

87. Colker \& Brudney, supra note 9 , at 83.

88. Id. 
can make rules in this area under the same circumstances in which it can make rules generally, but in this area uniquely, the court is not merely making rules, it is forcing the legislature to alter internal procedures and processes; it is forced to make legislative decisions more like judicial ones. Moreover, as argued above, the particular legal theories upon which courts base their judgments regarding whether the Congress has made a good case for its authority are, properly, ideological. Courts making rules are engaged in political choice in which the people have legitimate interests. Therefore, we should not be surprised that these interests will play out in deciding new appointments.

VI

\section{EXPLAINING POLITICIZATION}

Theoretically, Article I of the Constitution places the legislative power in Congress or, more accurately, jointly in Congress and in the Presidency, acting in accordance with the formalities of bicamerality and presentment. ${ }^{89}$ When this body - which we shall call the constitutional legislature-is capable of action, it will retain control of legislative authority. Under these political circumstances, though other entities-administrative agencies or courts in particular-may engage in lawmaking (in the sense of promulgating binding normative rules of general and prospective application), such activity takes place in the shadow of, and at the sufferance of, the constitutional legislature. Whatever rules are developed will tend to be ones that the constitutional legislature would accept. These are circumstances in which the legislature is practically sovereign. ${ }^{90}$

Courts and agencies are capable of independent or autonomous action where the constitutional legislature is too fragmented to react. ${ }^{91}$ In such circumstances, lawmaking will tend to migrate to those bodies that are capable of decisive action. In these conditions we see the development of such familiar entities as the "runaway" bureaucracy and the activist courts. The migration of legislative powers to agencies and courts places extraordinary burdens on these institutions. When courts can make politically consequential and more-or-less final decisions, anyone with an interest in those decisions has reason to try to frame those interests in the form of persuasive legal arguments. And those interested in judicial decisions have reason to seek to influence and, if possible, to control appointments to the courts and other legal institutions. In this sense, "judiciali-

89. U.S. CONST. art I., § 1; art. I, § 7, cl. 2.

90. We distinguish practical legislative sovereignty from the formal notion of parliamentary sovereignty that characterizes other legal systems. In France, the principle of parliamentary sovereignty implies that the parliament can do no wrong and so promulgated laws cannot be reviewed or altered by any body other than the parliament itself. As a result, the role of the French Constitutional Council is restricted to reviewing laws that have been passed in both chambers but not yet promulgated. After a law becomes official, however, it can only be changed by parliamentary action. See ANDREW KNAPP \& VINCENT WRIGHT, THE GOVERNMENT AND POLITICS OF FRANCE 61 (4th ed. 1989)

91. John Ferejohn \& Charles Shipan, Special Issue, Congressional Influence on Bureaucracy, 6 J.L. ECON. \& ORG. 1 (1990) (developing the idea that these same conditions are also indications that states are capable of independent political activity). 
zation" of politics tends to produce the politicization of courts. ${ }^{92}$ As a result, judicial decision-making tends to become politics carried on by other means.

How does this take place? I argue that the institutions of a liberal legal culture facilitate the conversion of ideological positions into "internal" legal positions. We can see this in the culture of legal training and in the core idea that every interest is entitled to competent legal representation and articulation. Well-trained lawyers are supposed to be able to state and articulate the most far-fetched claims, and judges are supposed to be able to respond to and weigh these arguments within the law. It is not surprising therefore that, at least in the United States, virtually every ideological or partisan position can be articulated in law-usually in different ways-as more or less defensible legal positions.

Moreover, as de Tocqueville noted long ago, America's political system is particularly open to the formation and proliferation of associations and interest groups. ${ }^{93}$ So, we have seen the emergence of a vast system of legal interest groups whose aims are to develop respectable jurisprudential positions that correspond to their particular partisan or ideological preferences, to recruit and nurture articulate advocates for these views, and to place them in positions of legal power. On the "left," we see such groups as the National Association for the Advancement of Colored People, National Organization for Women, National Resources Defense Council, American Civil Liberties Union, and many others. On the "right," there are the Pacific Legal Foundation, the Federalist Society, and many others. These organizations have been remarkably effective at seeking their political interests within the legal terrain in which deliberation and reasoning are the mode in which general rules are adopted and modified.

None of this would be so worrying if courts were simply expected to listen to these arguments put by the lawyers in front of them. There is much to be said for the practice of public interest groups, whatever their goals, putting forward amicus briefs stating the case for one decision or doctrinal amendment of another. Indeed, such a practice helps to articulate the general or societal interests that are considered in deciding cases. The problem is, however, that the makeup of bench and legal officialdom in general is permeable to the influence of the same interest groups.

So, in the United States, much of the "action" has to do with appointments. Legislators, knowing that they cannot control judicial rule-making in a variety of areas of public life, must try either to affect who sits on the bench or who makes arguments for the government. From John Adams' midnight appointments to the federal judiciary, through various court-packing schemes, to the removal of California judges over their death penalty votes, fights over who shall be a judge or a prosecutor have been regular issues of American politics. This is only to be expected. Prosecutors at all levels are politically appointedtypically by bare partisan majorities. Therefore, prosecutorial decisions, insofar as they involve the exercise of judgment in a world of scarcity and uncertainty

92. Ferejohn \& Pasquino, supra note 1.

93. See DE TOCQUEVILle, supra note 3. 
probably ought to be held to a principle of democratic accountability. But the same arguments seem a bit less convincing when it comes to the makeup of the judiciary itself. Still, we have chosen to staff the bench with partisan political appointees who require only a bare majority for their appointments. Not surprisingly, it is easy to characterize judges and courts in partisan terms within such a system.

None of this is to say that the judges themselves are behaving like partisan politicians: trading votes, brokering deals, or forming coalitions. I have little doubt that judges are deciding the cases before them in light of their own more or less coherent jurisprudential ideas about what the law requires. From the perspective of the outside observer, however, their behavior is nonetheless predictable from a simple model of ideological voting. ${ }^{94}$ Since it is so predictable, other political actors will tend to treat court decisions as political events and try to shape and influence them for their own political reasons.

It is worth pointing out that the American form of politicized courts is unusual in the advanced democratic world. This is so for many reasons. European legal traditions are probably not as pluralistic-many of the continental legal systems still see judicial decision-making as syllogistic-and there is probably not the same proliferation of legal interest groups in many of those nations. Moreover, appointments to ordinary courts are almost always bureaucratic-one enters the judiciary as one would enter a civil service job. And, though appointments to the new constitutional courts are made by political bodies, those appointments generally require super-majorities. This requirement prevents the appointment of judges with immoderate ideological views. Finally, courts in Europe are much less open to public scrutiny than are American courts. The constitutional courts deliberate in secret, issue per curiam opinions, and often do not permit the publication of dissents. The result is that interest groups are much less likely to be able to see how judges are ruling or voting and subsequently criticize or praise them for their actions on the bench. Thus, while I believe that European constitutional courts may be as political as U.S. courts in the sense of engaging in lawmaking in ways not subject to legislative control, they are much less partisan, and their ideology tends to be centrist.

\section{VII}

\section{CONCLUSION}

When conditions are favorable for courts to exercise legislative powers, they are free to do so across the board, whether or not the specific policy decisions are best made in legal settings. There is a mismatch between the positive conditions that permit judicialization and the normative justification of judge-made

94. JefFrey A. Segal \& Harold J. Spaeth, The Supreme Court and the Attitudinal MODEL 65 (1993) ("[T]he attitudinal model holds that the Supreme Court decides disputes in light of the facts of the case vis-à-vis the ideological attitudes and values of the justices. Simply put, Rehnquist votes the way he does because he is extremely conservative; Marshall voted the way he did because he was extremely liberal."). 
law. This is politically dangerous in various ways. It has the effect of politicizing courts-making judicial decisions appear to be politically motivated and making appointments to the bench matters of partisan contention-of reducing the legitimate abilities of the people or their representatives to legislate, and, less often, of provoking crude and heavy-handed electoral responses. There is a need, therefore, for courts to take care when they relocate specific legislative issues to legal settings, and taking such care requires the formulation of normative standards to guide the allocation of legislative authority.

What might such normative standards look like? I suggest that different kinds of legislation are appropriately made in different institutional settings. Courts are well suited to make certain kinds of legislative rules-rules that need to be developed in light of repeated experience in use, and that should answer to concerns about equality, due process, and justice. This is not to say that the legislature should not participate in making policy in these areas; I only argue that courts have an important and continuing role in regulating legislative activities in these areas. Similar considerations should govern when administrative agencies should legislate rules. Rules that need, for whatever reason, to be responsive to technical issues are often best formulated in settings where expertise is available and professional norms can shape the policy discourse.

But the desirability of developing and enforcing norms for governing the location of legislative authority is no assurance that such norms will develop or be applied. Specifically, it is doubtful that American judges protected by life tenure and chosen in partisan political processes can be relied upon to exercise precisely the kinds of nuanced restraint that would be called for. For that reason, I think it is inevitable that, under certain circumstances, judges will exercise legislative powers in areas where the legislature itself ought to do so. Or, perhaps worse, judges may resolve important disputes on an ad hoc basis and without regard to any general principle that can be applied to decide similar cases. Some scholars think that Bush v. Gore ${ }^{95}$ was such a case and that we should understand the attempt of some of the justices to assure the nation that they were not developing a new branch of equal protection doctrine (establishing and appealing to a general principle) as the surest sign that such exercise was inappropriate. Political reactions to such actions are inevitable and, whether they are successful or not, they have the effect over time of making the court into an explicitly political institution.

In the introduction, I suggested that it may make sense for Americans to consider some reforms that might alter the political dynamics of the Court. The reforms I suggested-requiring a supermajority in the Senate for appointments and limiting justices to a single nonrenewable term-are already in place in many European constitutional courts, and their empirical experience might be informative. A supermajority requirement for appointment would mean that newly appointed judges would have to be acceptable across party and ideologi-

95. 531 U.S. 98 (2000). 
cal lines. This would tend to discourage the appointment of ideologically extreme judges and would probably tend to lead to a court filled with judicial moderates. Of course, judicial minds can and do change over time, and there never can be an ironclad guarantee against judicial "drift." Still, fixing judicial terms would tend to alleviate such problems. Even if members did become extreme in some dimensions, they could not serve on the Court for more than ten or twelve years.

These two reforms, taken together, would likely lead to a different kind of internal decision-making culture in the Court. The members, being in broad agreement, would tend to see real chances for coming to consensual agreements on many cases. The Court would probably begin developing practices aimed at attaining broad agreement-even agreement based on widely shared principles-rather than settling for determining cases by the majoritarian rule of five. Such a development would lead to an increased confidence in the Court both among elected and appointed officials and among the public at large. Support for these conjectures can be obtained from the practices of other constitutional courts.

In Germany, for example, justices on the Constitutional Court rarely issue dissents but instead work largely by consensus in most cases. ${ }^{96}$ In addition, the names of the justices are not familiar to the public. ${ }^{97}$ Since new justices tend to be jurisprudential moderates by design, however, this phenomenon is not surprising. Consensus is, obviously, less difficult to achieve when most of the members are in broad agreement. Observation of the Italian and Spanish Constitutional Courts point to the same conclusions. Members and observers of those courts emphasize that consensus is always aimed for and is frequently achieved. ${ }^{98}$

Obviously, the European model has some limitations in a country as large and diverse as the United States. There is a chance that the Court would be reflective of the broad center of U.S. politics but that significant minorities would not see their views reflected. There is also a real concern that reforming the Court will affect substantive outcomes. It is not at all clear, however, that a Court comprised of members who are broadly acceptable across the political spectrum will be hostile to minorities. In any case, the fact that terms would be restricted would keep the court consistently open to new political forces.

A natural response to reform proposals-especially proposals that involve amending the Constitution-to ignore them because they are infeasible. With respect to imposing term limits on appointments, this is a plausible response. Such a reform would require mobilization of a very wide Article V coalition, and we know from experience how difficult such coalitions are to form. But a supermajority requirement does not require constitutional change. Such a reform can be implemented conventionally, as the British changed their constitu-

96. Ferejohn \& Pasquino, supra note 49.

97. Id.

98. $I d$. 
tion. If members of the Senate regarded a two-thirds majority as required for appointment, they could simply (but not necessarily easily) refuse to approve any nomination that failed to receive that level of support. Alternatively, Senators could take advantage of procedural rights under Senate rules to block consideration of members who lack filibuster-proof support. Things would be a little messy at first, of course, but such a stance could be defended on principled grounds and might well be sufficient to implement the change. Whether Senators would be capable of withstanding the partisan heat that would be put on them is another matter. 